\title{
Economic viability and production capacity of wind generated renewable hydrogen
}

\author{
M. Mohsin ${ }^{a}$, AK. Rasheed ${ }^{\mathrm{b} *}$, R. Saidur ${ }^{b, c}$ \\ ${ }^{a}$ College of Economics and Management, Nanjing University of Aeronautics and Astronautics, \\ 29 Jiangsu Avenue, Nanjing 211106, China \\ ${ }^{\mathrm{b}}$ Research Centre for Nano-Materials and Energy Technology (RCNMET), School of Science \\ and Technology, Sunway University, Bandar Sunway, Petaling Jaya, \\ 47500 Selangor Darul Ehsan, Malaysia \\ ${ }^{c}$ Department of Engineering, Lancaster University, LA1 4YW, United Kingdom
}

\begin{abstract}
Generally, wind to power conversion is calculated by assuming the quality of wind as measured with a Weibull probability distribution at wind speed during power generation. We build on this method by modifying the Weibull distributions to reflect the actual range of wind speeds and wind energy density. This was combined with log law that modifies wind speed based on the height from the ground, to derive the wind power potential at windy sites. The study also provides the levelized cost of renewable energy and hydrogen conversion capacity at the proposed sites. The calculated cost $(\$ / \mathrm{kWh})$ suggests that the commercial viability is not feasible. We have also electrolyzed the wind-generated electricity to measure the production capacity of renewable hydrogen. We found that all the sites considered are commercially viable for hydrogen production from wind-generated electricity. Wind generated electricity cost varies from $\$ 0.0844$ to $\$ 0.0864 \mathrm{~kW} / \mathrm{h}$, and the supply cost of renewable hydrogen is $\$ 5.30$ to $\$ 5.80 / \mathrm{kg}-\mathrm{H}_{2}$. Based on the findings, we propose a policy on renewable hydrogen fueled vehicles so that the consumption of fossil fuels could be reduced. This paper shall serve as a complete feasibility study on renewable hydrogen production and utilization.
\end{abstract}

Keywords: New model, Renewable energy, Hydrogen energy, Weibull distribution, Hydrogen production capacity, Levelized cost.

\footnotetext{
${ }^{*}$ Corresponding author. Tel.: +60374918622; Fax: +60356368204

Email address: khaliqr@sunway.edu.my (AK Rasheed); mumu@nuaa.edu.cn (Muhammad Mohsin)
} 


\section{Introduction}

Growing energy demands and climate regulations encourage the utilization of renewable energy resources including hydrogen energy. Continuous usage of fossil fuels will result in irrevocable damage of environment. Several nations around the globe are striving to provide access to clean and sustainable energy by 2030 [1]. Carbon based power systems should be exchanged with new renewable energy technologies that are able to balance energy demand-supply, ensure energy security, have less impact on climate change and economically viability. According to Renewable Global Status Report, renewable energy contributed 19.2\% of the total world's energy consumption in 2014. Among the several renewable energy resources, renewable hydrogen could be a major contributor to sustainable clean energy production and successful Millennium Development Goals (MDGs) [2]. Intergovernmental Panel on Climate Change (IPCC) [3] considers renewable hydrogen energy (RHE) to be the best substitute for fossil fuels. Moreover, RHE would help to ensure $100 \%$ integration of renewable energy. RHE can be generated through various resources such as wind, solar, geo-thermal and hybrid sources. RHE systems can improve energy security of developing nations including China and Japan, and help them in reducing China's $\mathrm{CO}_{2}$ emissions via scientific diversification, and minimizing dependence on imported fossil fuels.

Energy generation using solar systems typically costs 6 to 18 times higher than wind energy and wind turbine systems [4]. At present, hydrogen production through water electrolysis using wind energy is considered as a lowest life cycle greenhouse gases (GHG) emissions of all hydrogen production resources. Most works related to hydrogen production have ignored the regional characteristics of wind power potential to produce renewable hydrogen at country level [5]. Mostly traditional methodologies are adapted to select optimal wind sites and lack exploitation of latest technologies [6]. They have only used present value (PV) cost methods to measure the price of 
renewable energy. PV cost method combines discount rate and future cash flows, and it is hard to estimate the $100 \%$ accuracy of future value and discount rate. In addition, the PV cost method do not incorporate the increasing unit of energy production. Existing literature [7] partially enumerates the wind power potential, the cost of renewable energy and hydrogen production along with its capacity. Based on our knowledge, this is the first of its kind study that takes into account all the above-mentioned issues.

This study uses modified Weibull distribution function to characterize and select optimal wind sites and turbine configurations at a rich windy site to produce wind electricity for hydrogen production. We used a new modified model of the Weibull distribution function and log law, and electrolyze the wind-generated electricity to produce renewable hydrogen energy. Our paper additionally measures the Levelized cost of wind electricity generation via average incremental credit cost to measure the cost of renewable hydrogen production. The advantage of average incremental credit cost is associated with every increasing unit because, few costs are variable and some are fixed cost so the average incremental cost will be decrease with increasing every unit of energy production. We also introduced a new mathematical model to measure the hydrogen production capacity at any windy sites by introducing the wind topography of Pakistan as a practical case study, which shows the total wind power potential. Based on our findings, we suggest a policy to the government to reduce the energy shortfall by shifting vehicles from fossil fuel to hydrogen energy. Our study also provides an empirical estimation, economic viability of the hydrogen production and guidelines for $100 \%$ integration of renewable energy. In summary, our objective is focused towards the potential generation of renewable hydrogen from the windgenerated electricity at windy sites and its economic integration is the main objective of the study. 


\section{Literature Review}

Numerous studies have investigated the integration and design of the renewable hydrogen energy system. Measuring the availability of renewable energy resources for production of hydrogen with different statistical and mathematical calculations has also been a common trend [8,9]. Olateju et al., [10] explored the production of wind generated hydrogen and determination of potential sites using the measurement of capacity factor by Weibull distribution function over wind. Østergaard et al., [11] stated that wind turbine and heated pump hydrogen storage system provides a continuous supply of energy when energy activity is slow. Katsigiannis et al., [12] examined the multi-criteria assessment for the potential of hydrogen production systems through wind energy, gas turbine and photovoltaic system. Sacramento et al., [13] conducted a study on electrolytic hydrogen production for the Ceara state in Brazil. They observed that the energy consumption and the gross internal product per capita of the region would increase by using the renewable resources to produce hydrogen. Ball et al., [14] stated that hydrogen production through renewable wind energy by electrolyzing the water without carbon dioxide emission or other dangerous gases leads to an optimal energy mix, resulting in reduced dependency on fossil fuels. Dagdougui et al. [15] assessed the potential of the hydrogen generation using wind energy in the province of Cordoba in Argentina. They found that the potential supply of wind energy to produce hydrogen energy in that region is ten times higher than the required level of hydrogen energy for the entire vehicular transportation. Bekele et al. [16] conducted a study to determine the feasibility of hydrogen production using wind energy. Guo et al. [17] examined a wind-energy storage-system model for huge wind energy of China. Akpinar et al. [18] investigated the wind characteristics of (Elazig-Keban, Elazig-Agin, Elazig and Elazig-Maden) by using probabilistic distributions, Maximum Entropy Principle, and traditional normal Weibull distribution through singly truncated application. Mohammadi et al., [19] used six statistical techniques including graphical method 
shows a weak efficiency while, Lysen empirical method, Justus empirical methods, maximum likelihood method, energy pattern factor method and modified maximum likelihood method shows a strong efficiency to determine the scale (c) parameters and shape (k) parameters of Weibull distribution function to measure wind power density. Ozay et al., [20] analyzed wind characteristics including wind direction, frequency distribution of wind speed, mean speed, scale and shape parameter of Izmir region in Turkey by using two parameter Weibull distribution function. Shu et al., [21] measured the characteristics of renewable energy sources of Hong Kong through traditional Weibull distribution function.

Hill et al., [22] measured the parameters of Weibull probability and Weibull density distribution function for three different sites and found that statistical values of scale and shape parameters for these stations are wide-ranging. Tsekouras et al., [23] proposed probability distribution function by time series data. They estimated the distributional parameters of probability distribution function. Wais et al., [24] concluded that the accurate evaluation of Weibull shape and scale parameters is necessary for the wind energy potential estimation. Wind speed alone does not provide the clear understanding of wind speed distribution and wind potential of any sites in the region, because it is also possible that the same average wind speed have different parameters of Weibull distribution function. Khahro et al., [25] analyzed the numerical characteristics of wind speed to obtain an exact measurement and estimation of wind potential. They focused on wind parameters of Weibull distribution function by using two component mixture Weibull distributions with five parameters and winds power potential. Shin et al., [26] demonstrated that the two-component mixture of Weibull distribution function could be considered as a useful estimation because it provides a heterogeneous wind regime. Boudries et al., [27] predicted the renewable hydrogen energy system for households using a storage medium 
of renewable hydrogen. Dincer et al., [28] proposed an optimization model of a renewable energy system for zero/low energy structure. Oh et al, [29] measured a techno-economic viability analysis of an integrated renewable energy in order to meet the demand of households in Greece.

Kalinci et al., [30] analyzed a hybrid system consisting of wind turbine and electrolyzer units. Kalinci et al. [31] studied hydrogen energy system in an Island in Turkey and done technoeconomic analysis of hybrid renewable energy by hydrogen generation and its storage. . Onovwiona et al., [32] suggested a hydrogen turbine energy system for the domestic households and residential application in which micro-cogeneration has ability to produce electricity and thermal energy from a single source of fuel. Many studies have been done in different regions of the world with outstanding wind conditions, such as Ireland, Norway and the Faroe Islands and they concluded that wind potential pattern to produce renewable energy is similar to Denmark. Mohammed et al., [33] considered the incorporation of a hybrid wind and a renewable hydrogen system to ensure the delivery of a stable $100 \%$ renewable energy contribution. The result revealed that although the storage mechanism of renewable hydrogen is costly and inefficient due to higher capital cost, it has numerous advantages towards $100 \%$ integration of renewable energy and environment friendly [34]. Lund et al, [35] concluded that the high capital cost of fuel cells makes costly renewable storage systems but by using electrolyzer procedure to produce and sell the renewable hydrogen to responsive load.

Jebaraj et al., [36] investigated the role of renewable energy technology to climate change adaptation via long-range energy options planning and estimated the possible potential reductions of emissions by using different renewable technologies. The industrial application of renewable hydrogen covers from fertilizer production, refineries, fueling of vehicles and metal extracting [37]. Sarrias-Mena et al., [38] studied the electrochemical performance internal parameters of the 
electrolyzer process including different elements namely the membrane, cathode, anode and voltage accessory. They also explored the fractional pressure required to operate the electrolyzer process. Valverde-Isorna et al., [39] proposed EZ model in order to make a complete comparison with other models and methodologies to perform the electrolyzer process in order to produce renewable hydrogen energy. They also suggest that the cathode and anode accessory perform the similar function, which is to provision of oxygen concentration and hydrogen concentration separately. Currently the hybrid renewable power structure for the hydrogen production mainly concentrating on the wind, and geothermal energy options to produce renewable hydrogen energy [40]. In existing literature, different researchers have used different conventional methods to estimate the wind power potential and suggested various mechanisms to convert this windgenerated electricity into hydrogen and they used traditional cost measurement techniques, which has influenced us to come up with new methodologies to ensure the robustness of the results.

\section{Methodology to assess wind electricity for hydrogen production}

Data was obtained from the reports of the meteorological department of Pakistan. According to Metrological departments of Pakistan, wind data for this study is measured at heights of 30 meters, 50 meters, 60 meter and 80 meter above from ground level at different locations in northern areas of Pakistan. This section will measure the wind potential to generate electricity for hydrogen production. As in earlier work, the Weibull distribution function is a fundamental building block for the estimation of wind characteristics [41]. Nevertheless, we indicate how we have estimated the average wind speed, wind power density, wind power potential, shape parameter, scale parameter and capacity factors with new hybrid methodology, at different hub height to measure the wind potential of electricity production at proposed sites. For the estimation of wind characteristics we begin with, 


$$
f(u)=\frac{K}{c}\left(\frac{u}{c}\right)^{k-1} \times \exp \left(\frac{-u}{c}\right)^{K}
$$

$\mathrm{K}$ is a dimensionless shape parameter and it is a measurement of width of distribution, $\mathrm{c}$ is called scale parameter, which is very closely near to mean of the wind speed, $u$ is the wind speed and its unit is $\mathrm{m} / \mathrm{s}$. The shape parameter $\mathrm{K}$ can be calculated with mean and standard deviation of the wind [42] as follows:

To solve the equation (1) we use the following parameters

$$
\mathrm{K}=\left(\frac{\sigma}{\overline{\mathrm{u}}}\right)^{-10.86}
$$

Where $1 \leq K \leq 10$

The scale parameter (c) can be expressed as:

$$
c=\frac{\bar{u}}{r\left(1+\frac{1}{K}\right)}
$$

$u$ is the mean and $\sigma$ is called standard deviation of the wind speed and it can be calculated as

$$
\begin{gathered}
\overline{\mathrm{u}}=\frac{1}{\mathrm{n}} \sum_{\mathrm{i}=1}^{\mathrm{n}} \mathrm{u}_{\mathrm{i}} \\
\sigma=\left[\sum_{i=1}^{N} \frac{(u-\bar{u})^{2}}{N-1}\right]^{0.5}
\end{gathered}
$$

Where $r$ of gamma function can be determined by following function.

$$
r(m)=\int_{0}^{\infty} \epsilon^{m-1} \exp (-\epsilon) d \in
$$

$\epsilon$ is the constant real irrational number and its value is $\epsilon=2.7182818284590$

The Gamma function can be computed as,

$$
r(m)=\sqrt{2 \pi m}\left(m^{m-1}\right)\left[1+\frac{1}{12 m}+\frac{1}{288 m^{2}}-\frac{139}{51840 m^{3}} \ldots . .\right]
$$


Only investigation of wind speed doesn't represent a true picture of wind potential because wind speed's frequency distribution and kinetic energy suppressed in the wind power density. It normally depends upon the wind speed cube, frequency distribution of wind speed, velocity v, area A of turbine blade with air density $\rho$. The unit of velocity is $(\mathrm{m} / \mathrm{s}),\left(\mathrm{m}^{2}\right)$ is the unit of Area and $\left(\mathrm{Kg} / \mathrm{m}^{3}\right)$ is the unit of density. Parcel of wind energy having kinetic energy is as follows [43],

$$
\mathrm{E}=\frac{1}{2} \mathrm{~m} \mathrm{v}^{2} \text { but we substitute } \mathrm{v} \text { as a } \mathrm{u} \text { so } \mathrm{v}=\mathrm{u} \text { so } \mathrm{E}=\frac{1}{2} \mathrm{mu} \mathrm{u}^{2}
$$

From this equation power density can be generated as

$$
\mathrm{P}=\mathrm{e}^{-} / \mathrm{t}^{-}=\frac{1}{2} \frac{\mathrm{dm}}{\mathrm{dt}} \mathrm{u} 2
$$

$\frac{d m}{d t}$ is air following mass w.r.t to time $t$.

By fluid dynamics it is proved that

$$
\frac{\mathrm{dm}}{\mathrm{dt}}=\phi \mathrm{Au}
$$

Volume of the cylindrical cross section can be expressed as

$$
\mathrm{u}=\pi \mathrm{l} \mathrm{r}^{2}
$$

$l$ Is length and $\mathrm{r}$ is the radius of cylinder, Velocity of wind is $\mathrm{u}$, it travel the distance $\mathrm{L}$ in time $\mathrm{t}$, so it is

$$
\begin{gathered}
l=\text { ut } \quad \text { substituting values in equation (11) } \\
u=\pi u t r^{2}
\end{gathered}
$$

Mass of wind is as follows

$$
\mathrm{m}=\phi \text { Aut }
$$

By differentiating 


$$
\frac{\mathrm{dm}}{\mathrm{dt}}=\phi A \mathrm{u} \frac{\mathrm{d}}{\mathrm{dt}(\mathrm{t})}=\phi A v
$$

$\phi$ is called the density of wind;

$$
\text { Power is } P=\frac{1}{2} \frac{\mathrm{dm}}{\mathrm{dt}} \mathrm{u}^{2}
$$

Substitute the value of $\frac{\mathrm{dm}}{\mathrm{dt}}$

$$
\mathrm{P}=\frac{1}{2} \phi \mathrm{Au} \mathrm{T} / \mathrm{t} \mathrm{u} \mathrm{u}^{2} ; \mathrm{P}=\frac{1}{2} \phi \mathrm{Au}^{3}
$$

Power density can be written as

$$
\mathrm{P} / \mathrm{A}=\frac{1}{2} \phi \mathrm{u}^{3}
$$

Wind density at the mean sea level is $1.225 \mathrm{~kg} / \mathrm{m}^{3}$ and it mainly depends on the wind velocity. Wind speed increases with increasing height. It shows the direct relationship between hub height and wind speed but generally wind speeds are observed at different heights on a wind turbine. In such cases, although Weibull distribution technique is a popular technique to estimate the relative parameters, we use the log law which modifies wind speed based on the height from the [44] ground, to derive the wind power potential because it provides a best fit of wind speed at increasing height ,

$$
\frac{u}{u_{R}}=\log \frac{\mathrm{l}_{\mathrm{n}}\left(\frac{\mathrm{H}}{\mathrm{H}_{\circ}}\right)}{\mathrm{l}_{\mathrm{n}}\left(\mathrm{H}_{\mathrm{R}} / \mathrm{H}^{\circ}\right)}
$$

$\mathrm{u}$ is wind speed at height $\mathrm{H}$ and $\mathrm{u}_{\mathrm{R}}$ is the wind speed height $\mathrm{H}_{\mathrm{R}}$. Roughness length $\mathrm{H}_{\mathrm{o}}$ is related to displacement height and displacement height is the height over roughness elements where there is a free flow. Moreover, accumulated annual energy output of a wind energy project is called the capacity factor of wind energy turbines. It varies from site to site and turbine to the turbine. It depends upon the capacity of the machine to produce electricity and mainly the wind speed of 
proposed sites. Economic viability of a wind turbine is expressed by capacity factor (CF), it is the ratio of average power yield $\left(\mathrm{P}_{\mathrm{o}}\right)$ to the stated power $(\mathrm{Pt})$ of the turbine. It is the best criteria for selecting any turbine.

$$
C_{f}=\frac{P_{o}}{P t}
$$

$P_{o}$ Can be determined from Weibull probability density function as:

$$
P_{o}=\int_{u c i}^{u c o} \rho u f(u) d u
$$

Power generated through a pitch-controlled turbine is calculated from the power curve. The variable $f(u)$ is (operational wind speed) is the function of the duration of the wind speed.ucois the cut- out wind speed and $u c i$ is the cut-in wind speed, $\rho u$ is wind turbines power curve,Pt is rated wind speed capacity of the turbine. Wind turbine power generation $(\mathrm{P})$ is approximated by the power curve,

$$
P_{t}=\frac{1}{2} \rho A C_{P} u^{3}
$$

Putting values of $\mathrm{P}_{\mathrm{t}}$ and $P_{o}$ in equation (11)

$$
C_{f}=\frac{P_{o}}{P_{t}}=\frac{\int_{u c i}^{u c o} \rho u f(u) d u}{\frac{1}{2} \rho A C_{P} u^{3}}
$$

Power generated through a pitch-controlled turbine is calculated from the power curve. Capacity factor can be shown with $C_{f}$.

\subsection{Cost of Production}

The Levelized cost of electricity is a valuable economic indicator to compare the cost of different production types of electricity calculated in terms of the cost per unit of electricity output (\$/MWh). It includes carbon, fuel, capital and other sources of cost. The Levelized cost of electricity can be measured by the annual cost of energy production divided by annual energy 
production [45].Annual energy production (AEP) is inversely proportional to the annual energy production. By increasing of wind resources, the total cost remains constant but the cost per unit energy will decrease. The annual fixed charge rate transfer the lump-sum investment into annual payment. Kanchana et al, [46] measured the average incremental energy credit of the wind park over the study period $(\$ / \mathrm{MW} \mathrm{h})$ as levelised cost as,

$$
A I C E n=\frac{\frac{\sum_{n=1}^{N}\left(F C_{R n}-F C_{W n}\right)+\left(V O \& M_{R n}-V O \& M_{W n}\right)+\left(E N S_{R n}+E N S_{W n}\right)}{(1+i)^{n}}}{\sum_{n=1}^{N}(1+i)^{n}}
$$

AICEn is the average incremental energy credit of wind sites (available for hydrogen production) over the study period ( $\$ / M W h)$. $N$ is Study period (Years), i is discount rate, $F C_{R n}$ is the fuel cost of the year (n) under reference case, $\mathrm{FC}_{\mathrm{W}_{n}}$ is fuel cost of year $\mathrm{n}$ under wind power case, $\mathrm{VO} \& \mathrm{M}_{\mathrm{Rn}}$ is variable $O \& M$ in year $n$ under reference case. $V O \& M_{W n}$ is variable $O \& M$ in the year $n$ under wind power case, $\mathrm{ENS}_{\mathrm{RN}}$ is electricity costs in year $\mathrm{n}$ under reference case, $\mathrm{ENS}_{\mathrm{WN}}$ is electricity costs of year $\mathrm{n}$ under wind power case, $\mathrm{WG}_{\mathrm{n}}$ is the wind electricity generation in year $\mathrm{n}$. Although this model measured the cost of electricity in the term of $(\$ / M W h)$ but it ignored the fundamental pillars of capital expenditure and operational expenditure of levied cost of the electricity presented by the national renewable energy laboratory as,

$$
L C O E=\frac{(\text { Capex } \times C F R)+\text { opex }}{A E P}
$$

LCOE is the Levelized cost of energy ( $\$ / M W h), F C R$ is the fixed change rate (\%), Capex is capital expenditures $(\$ / M W h), \mathrm{AEP}_{\text {net }}$ is the net average annual energy production (MWh/year), Opex is the operational expenditure ( $\$ / \mathrm{MWh})$. To measure the per unit cost of wind energy in $(\$ / \mathrm{kWh})$ we can measure as, 
$\mathrm{C}_{\mathrm{cu}}$ is per unit cost in $(\$ / \mathrm{kWh})$. Three basic pillars into the Levelized cost of electricity are operational expenditures (OPEX), capital expenditures (CAPEX) and annual energy production (AEP). The fourth basic pillar is the fixed charge rate (FCR) which symbolize the amount of revenue required to pay the capital including return on debt, return on equity taxes and depreciation associated to the CAPEX investment during the expected project life of the wind park on an annual basis. All analysis and LCOE results are in constant 2015 dollars throughout the report unless otherwise noted. National Renewable Energy Laboratory (NREL) has breakdown the structures of Levelized cost in order to organize and provide a general terminology across varying technology. Study provides a description about each component of the Levelized cost of electricity such as CAPEX, OPEX, AEP and FCR. Fix charge rate (FCR) can be calculated as,

$$
r=\frac{\mathrm{r} \times(1+\mathrm{r}) \mathrm{t}}{(1+\mathrm{r}) \mathrm{t}-1}
$$

where $r$ is the current interest rate.

\subsection{Electrolysis modeling}

Renewable Hydrogen energy can be generated through water electrolysis by using the wind

renewable electricity generated through electricity generation systems $E_{t}^{R E S}$. To operate electrolysis systems polymer alkaline electrolyze system has been considered in the study which is a scientifically proven process and it is measured due to its simple use and comparatively cheaper price. For production of $1 \mathrm{~kg}$ of renewable hydrogen the $53.4 \mathrm{kWh}$ of electricity and $10.6 \mathrm{~kg}$ of water is needed. The amount of renewable hydrogen from the process of electrolyzer $\mathrm{H}_{\mathrm{kt}}^{\mathrm{el}}$ is determined using the following model $[47,48]$, 


$$
H_{k t}^{e l}=\vartheta_{j t}^{e l} E_{t}^{R E S} \quad \forall_{\mathrm{j}} \in \mathrm{J}^{\mathrm{el}}, \mathrm{t}=1, \ldots \ldots \ldots \ldots \ldots \ldots
$$

where $\vartheta_{\mathrm{jt}}^{\mathrm{el}} \mathrm{j}$ is the electrolyzer operation efficiency and it includes the extra energy consumption for additional apparatus operations. And simultaneously the amount of oxygen produced by the process of this electrolysis system is $\mathrm{O}_{\mathrm{kt}}^{\mathrm{el}}$ and it is calculated with following model,

$$
O_{k t}^{e l}=\mu_{j}^{o / h} H_{j t}^{e l} \quad \forall_{\mathrm{j}} \in \mathrm{J}^{\mathrm{el}}, \mathrm{t}=1, \ldots \ldots \ldots \ldots . . . \mathrm{n}
$$

where $\mu_{\mathrm{j}}^{\mathrm{o} / \mathrm{h}} \mathrm{j}$ is the ratios of produced hydrogen and produced oxygenic the system of electrolyzer $\mathrm{j} \in \mathrm{J}_{\mathrm{el}}$. To meet the demand and supply of renewable hydrogen the number of parallel units of electrolyzer are required. The quantity of renewable hydrogen produced through an electrolysis system $\mathrm{H}_{\mathrm{jt}}$ in the time period $(\mathrm{kg} /$ period) is calculated by the following equation,

$$
\mathrm{H}_{\mathrm{jt}}=\mathrm{M}_{\mathrm{t}} N_{j t}^{e l} H_{j t}^{e l} \forall_{\mathrm{j}} \in \mathrm{J}^{\mathrm{el}}, \mathrm{t}=1, \ldots \ldots \ldots \ldots . . . \mathrm{n}
$$

where $\mathrm{N}_{\mathrm{jt}}^{\mathrm{el}}$ is the number electrolyzer in the system and $\mathrm{M}_{\mathrm{t}}$ is the number of hours counted in the electrolyzer system.

\section{Mechanism of PEM electrolysis}

Electrolysis became a cheap and popular hydrogen production method worldwide. Three types of electrolyze rare identified in the hydrogen production literature. They are polymer electrolyte membrane (PEM), alkaline and high temperature solid oxide electrolyzer (SOE). Among all these, alkaline water electrolyzer is considered as a mature technology. These are safe, reliable and globally counted as a most extended electrolysis technology at the commercial level. It can be seen from Figure (1) that, water $\left(\mathrm{H}_{2} \mathrm{O}\right)$ decomposition of oxygen $\left(\mathrm{O}_{2}\right)$ and hydrogen gas $\left(\mathrm{H}_{2}\right)$ due to passing through an electric current from water is called electrolysis of water. As a result of water decomposition breathing oxygen can be produced and hydrogen gas can be 
produced for fuel purpose. Inert metal (stainless steel, platinum, or iridium) is used to make two electrodes which are connected with electric power. Both electrodes and plates are placed in the water. Hydrogen will appear at the negatively charged electrode, which is also called the cathode, while oxygen will appear at the positive charge side, which is also called the anode. The hydrogen amount produced in this process is double that of oxygen production. At the global level production of hydrogen, more than $85 \%$ is derived from the steam reforming processes which use fossil fuels at large and small size.

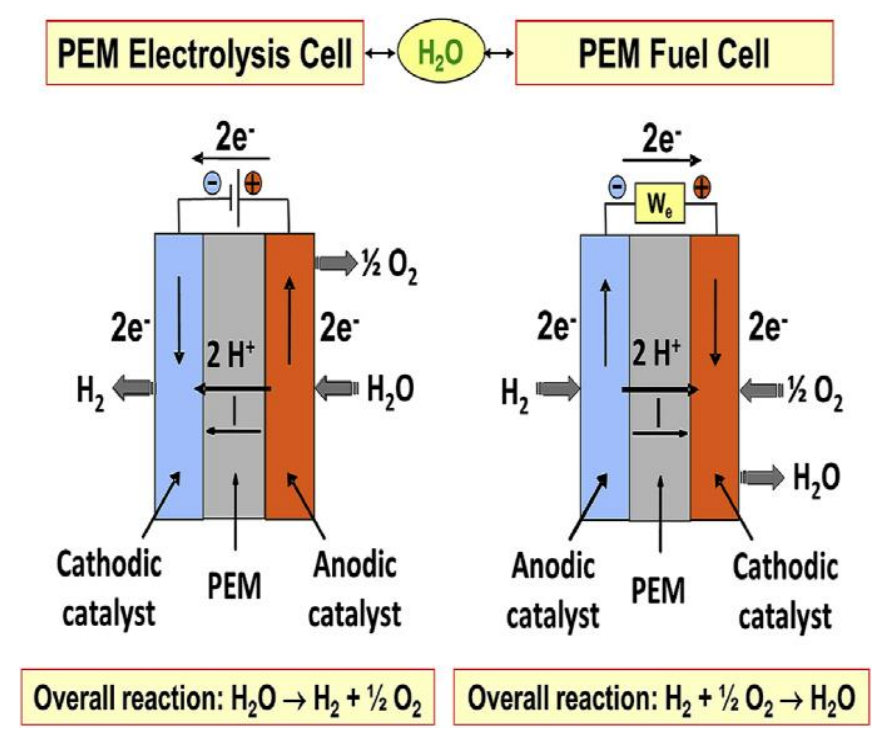

Figure.1 Electrolysis process

In the polymer electrolyte membrane electrolyzer, there is a solid plastic, which is also called the electrolyte. Water reaction with the anode yields the results of a configuration of positively charged hydrogen ions and oxygen ions. Then hydrogen ions move towards the cathode. Finally, the hydrogen gas will form at the cathode plate [49]. Currently hydrogen is identified as an environmentally friendly fuel worldwide. In addition, hydrogen is a recyclable element. After burning it converts into water. Hydrogen can be a viable substitute for diesel and gasoline. Hydrogen can be produced with an environmentally friendly source of wind energy with minimum 
cost. Wind power costs have continually descended compared too many other methods and technologies over the last five years. It is now approaching the lowest level cost where it can compete with other conservative technologies.

\subsection{Application: the case of Pakistan}

Pakistan is facing a major energy crisis over the past few years. The electricity industry has numerous problems including insufficient collection rates, line losses, high natural gas subsidies, power generation theft, expensive furnace oil and the older transmission network. Also the month of May, June, July and August are extremely hot in Pakistan. At, 28 June 2015, a great heat stroke and the heat wave killed 1200 people in the city of Karachi. Nearly 67,000 heatstroke patients were treated in different hospitals of Karachi (www.aljazeera.com) during heat wave in that summer. In the summer season, there is a huge energy shortfall in Pakistan so there is an emergency need to bridge up the energy crises in summer in Karachi city to arrest this problem. Pakistan is a rich country in geographic aspects and the wind blows 24 hour in many areas of the country. Pakistan wind energy production capacity is $5 \mathrm{MW} / \mathrm{km}^{2}$ in windy areas [50]. Wind measurement data of southern areas of Pakistan has been analyzed form 47 towers at a height of $30 \mathrm{~m}$ and $50 \mathrm{~m}$ because southern areas of Pakistan consist of mountains. 
Table1: Wind energy capacity as per guideline of National Renewable Energy Laboratory (NREL)

\begin{tabular}{cccccc}
\hline Class & Wind power $\left(\mathrm{w} / \mathrm{m}^{2}\right)$ & Speed $(\mathrm{m} / \mathrm{s})$ & Area $\left(\mathrm{Km}^{2}\right)$ & Windy area & Electricity capacity (MW) \\
\hline 7 & $>800$ & $>8.6$ & 796 & $0.1 \%$ & 3980 \\
6 & $600-800$ & $7.8-8.6$ & 2388 & $0.3 \%$ & 11940 \\
5 & $500-600$ & $7.4-7.8$ & 3980 & $0.5 \%$ & 19900 \\
4 & $400-500$ & $6.9-7.6$ & 16718 & $2.1 \%$ & 83590 \\
\hline
\end{tabular}

USAID Wind Resource Assessment and mapping for Afghanistan and Paksitan (2006)

According to area wise capacity of wind electricity production, Pakistan has been classified as a different wind characteristics and the availability of wind in the country. Table 1 shows that, Pakistan land is $803,950 \mathrm{~km}^{2}$ and $3 \%$ of the total land is 24 hour wind availability of excess wind speed and other wind characteristics so the total capacity of wind electricity generation is $1,19,410$ MW and total demand is $21,153 \mathrm{MW}$.

\section{Results and discussions}

\subsection{Wind characteristics for hydrogen production}

From table 2 the annual average wind speed is $6.4 \mathrm{~m} / \mathrm{s}$ at 50 -meter height. The highest wind speed $8.6 \mathrm{~m} / \mathrm{s}$ is observed in June and the average wind speed is more than $5 \mathrm{~m} / \mathrm{s}$. According to wind frequency distribution records (WFDR), during 76\% of the time the average wind speed is $5.1 \mathrm{~m} / \mathrm{s}$ or above. Baghan's annual power density is $276.3 \mathrm{~W} / \mathrm{m}^{2}$. Annual power production with a $600-\mathrm{kW}$ wind turbine is 1.2 million $\mathrm{kWh}$. It shows that the capacity factor of Baghan is $23 \%$ which is internationally considered suitable for wind power project installation. The annual 
average wind speed (table.2) DHA Karachi is $5.9 \mathrm{~m} / \mathrm{s}$ at 50 -meter height. During March and September average wind speed is more than $5 \mathrm{~m} / \mathrm{s}$ and the highest wind speed is $9.1 \mathrm{~m} / \mathrm{s}$ in July. Annually wind variation records shows that the maximum wind speed is available in the evening times. 
Table.2: Wind characteristics

\begin{tabular}{|c|c|c|c|c|c|c|c|c|c|c|c|c|c|c|c|c|c|c|c|c|c|c|c|c|}
\hline \multirow{2}{*}{ Month } & \multicolumn{4}{|c|}{$u(\mathrm{~m} / \mathrm{s})$} & \multicolumn{4}{|c|}{$\mathrm{C}(\mathrm{m} / \mathrm{s})$} & \multicolumn{4}{|c|}{ K } & \multicolumn{4}{|c|}{$\rho\left(\mathrm{w} / \mathbf{m}^{2}\right)$} & \multicolumn{4}{|c|}{$C_{f}(\%)$} & \multicolumn{4}{|c|}{$\operatorname{Re} \sim \mathrm{MWh}$} \\
\hline & $\mathrm{S}_{1}$ & $\mathrm{~S}_{2}$ & $\mathrm{~S}_{3}$ & $\mathrm{~S}_{4}$ & $\mathrm{~S}_{1}$ & $\mathrm{~S}_{2}$ & $\mathrm{~S}_{3}$ & $\mathrm{~S}_{4}$ & $\mathrm{~S}_{1}$ & $\mathrm{~S}_{2}$ & $\mathrm{~S}_{3}$ & $\mathrm{~S}_{4}$ & $\mathrm{~S}_{1}$ & $\mathrm{~S}_{2}$ & $\mathrm{~S}_{3}$ & $\mathrm{~S}_{4}$ & $\mathrm{~S}_{1}$ & $\mathrm{~S}_{2}$ & $\mathrm{~S}_{3}$ & $\mathrm{~S}_{4}$ & $\mathrm{~S}_{1}$ & $\mathrm{~S}_{2}$ & $\mathrm{~S}_{3}$ & $\mathrm{~S}_{4}$ \\
\hline May & 7.9 & 7.4 & 7.7 & 9.3 & 8.9 & 8.4 & 8.7 & 10.4 & 2.7 & 3.3 & 2.7 & $\begin{array}{l}2 . \\
5 \\
\end{array}$ & 458.3 & 346.4 & 428.4 & $\begin{array}{c}772 . \\
8\end{array}$ & 0.36 & 0.31 & 0.34 & 0.47 & 160 & 139 & 152 & 209 \\
\hline June & 8.6 & 7.7 & 9.1 & 10.6 & 9.7 & 8.7 & 10 & 11.2 & 2.6 & 3.0 & 2.8 & $\begin{array}{l}2 . \\
3 \\
\end{array}$ & 616.8 & 404.5 & 683.5 & 1028 & 0.42 & 0.34 & 0.46 & 0.50 & 180 & 147 & 199 & 218 \\
\hline July & 8.3 & 9.0 & 8.5 & 10.4 & 9.4 & 10. & 9.4 & 11.3 & 2.6 & 3.4 & 2.5 & $\begin{array}{l}2 . \\
5\end{array}$ & 549.6 & 620.3 & 560.3 & $\begin{array}{c}981 . \\
3\end{array}$ & 0.40 & 0.47 & 0.39 & 0.53 & 180 & 209 & 176 & 235 \\
\hline Aug & 8.4 & 8.1 & 7.5 & 9.7 & 9.4 & 9.1 & 8.7 & 10.5 & 2.9 & 3.2 & 2.9 & $\begin{array}{c}2 . \\
5\end{array}$ & 515.9 & 447.6 & 404.5 & $\begin{array}{c}784 . \\
3\end{array}$ & 0.40 & 0.38 & 0.34 & 0.47 & 180 & 168 & 151 & 212 \\
\hline
\end{tabular}


While $S_{1}$ stand for Baghan site, $S_{2}$ for DHA Karachi, $S_{3}$ for Golarchi and $S_{4}$ stands for Nooriabad site. $R_{e}$ is renewable electricity production at any site. $C_{f}$ is capacity factor and its measured in percentage. $\rho$ is density of the wind. $\mathrm{R}_{\mathrm{e}}$ is measured in $\left(\mathrm{W} / \mathrm{m}^{2}\right)$. According to WFDR, during $73 \%$ of the time the average wind speed is $5 \mathrm{~m} / \mathrm{s}$ or above. DHA Karachi annual power density is $241 \mathrm{~W} / \mathrm{m}^{2}$. It shows that the capacity factor of DHA Karachi is $21 \%$ which is internationally accepted for the wind power project installation. Golarchi annual average (Table2) wind speed is $6.4 \mathrm{~m} / \mathrm{s}$ at 50 -meter height. Except March and October, the average wind speed is more than $5 \mathrm{~m} / \mathrm{s}$ and the highest wind speed is $9.2 \mathrm{~m} / \mathrm{s}$ in June. According to WFDR, during $78 \%$ of the time the average wind speed is $5.1 \mathrm{~m} / \mathrm{s}$ or above. Golarchi annual power density is $283.4 \mathrm{~W} / \mathrm{m}^{2}$ and the capacity factor of Golarchi is $23 \%$ which is internationally accepted for wind power project installation. The annual average (table2) wind speed is $7.0 \mathrm{~m} / \mathrm{s}$ at 50 -meter height at Nooriabad. From March to September the highest wind speed $10.6 \mathrm{~m} / \mathrm{s}$ is observed in June and the average wind speed is more than 5 $\mathrm{m} / \mathrm{s}$. According to WFDR, during $79 \%$ of the time the average wind speed is $5.1 \mathrm{~m} / \mathrm{s}$ or above. Nooriabad annual power density is $455.3 \mathrm{~W} / \mathrm{m}^{2}$. Annual power production with a $600 \mathrm{KW}$ wind turbine produces 1.5 million $\mathrm{kWh}$. It shows that the capacity factor of Nooriabad is $29 \%$ which is internationally accepted for wind power project installation.

Excess flow of wind is necessary to produce electricity which is further required to produce hydrogen. Hydrogen via wind energy in four proposed sites of Pakistan can fuel 10545 cars annually by using the wind turbines of high quality models. Further, the atomic weight of hydrogen is 1 as it is a light element but in liquid form, having a density of $0.04 \mathrm{~g} / \mathrm{cm}^{3}$. Comparing the two energy sources gasoline and hydrogen, a $25 \mathrm{~kg}$ of gasoline is equal to $9.5 \mathrm{~kg}$ of hydrogen. A $25 \mathrm{~kg}$ of gasoline can be stored in a $14 \mathrm{~kg}$ tank but $25 \mathrm{~kg}$ hydrogen storage requires the tank of $145 \mathrm{~kg}$ mass. The reason is that volume of gasoline fuel is 4 times smaller than hydrogen fuels. As a result, we conclude that hydrogen fuel efficiency is 1.33 better than gasoline fuel for automobiles. 
Table 3:The summary of average Wind speed, $\mathrm{C}, \mathrm{K}, C_{f}, \mathrm{H} 2$ production and power density

\begin{tabular}{llccccc}
\hline Sites & $\boldsymbol{u}(\mathbf{m} / \mathbf{s})$ & $\mathbf{c}(\mathbf{m} / \mathbf{s})$ & $\mathbf{K}$ & $\boldsymbol{\rho}\left(\mathbf{w} / \mathbf{m}^{2}\right)$ & $\boldsymbol{C}_{\boldsymbol{f}}$ & $\mathbf{H}_{\mathbf{2}}(\mathbf{k g} / \mathbf{d a y})$ \\
\hline Baghan & 8.30 & 09.35 & 2.70 & 535.12 & 0.40 & 2519 \\
DHA K & 8.60 & 09.10 & 3.23 & 454.70 & 0.39 & 2404 \\
Golarchi & 8.20 & 09.28 & 2.73 & 520.00 & 0.40 & 2460 \\
Nooriabad & 10.0 & 10.80 & 2.45 & 891.60 & 0.50 & 3162 \\
\hline
\end{tabular}

Different size wind turbines of the larger diameter rotors could be used to produce the maximum hydrogen energy in Pakistan. Nooriabad has (table.3) $3162 \mathrm{~kg} /$ day potential of hydrogen production because the average capacity factor at Nooriabad is 0.50 in the summer season. As per NREL guideline a 0.25 capacity in factor is enough to install a wind project. This suggests that DHA Karachi would have a minimal potential of hydrogen production since its capacity factor is 0.39 in the summer season. But still this site meets the requirements of capacity factor given by NERL guidelines for wind power project installation.

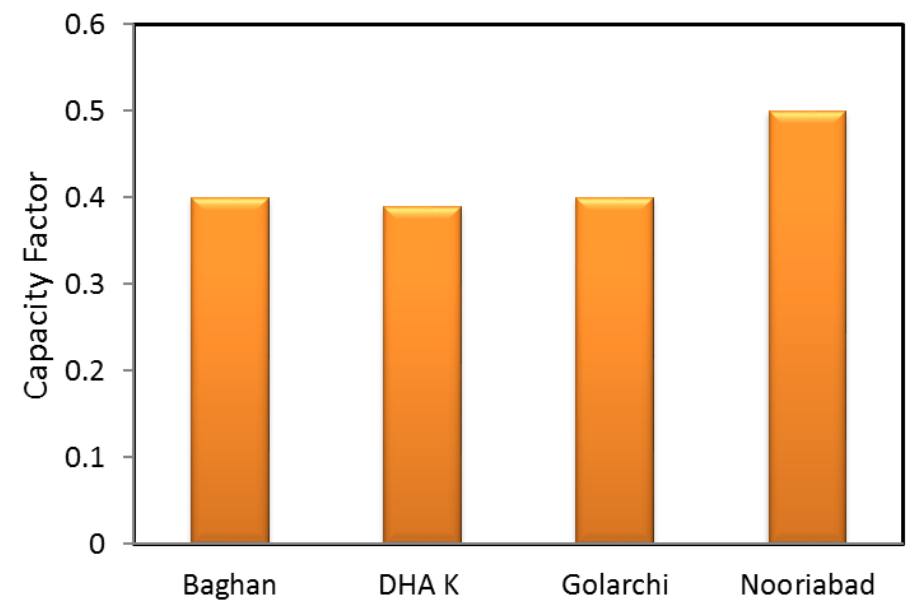

Figure 2. Capacity factor of the sites

Fig. 2 shows that capacity factor of each site is greater than 0.25 which are suitable for the wind power project. 


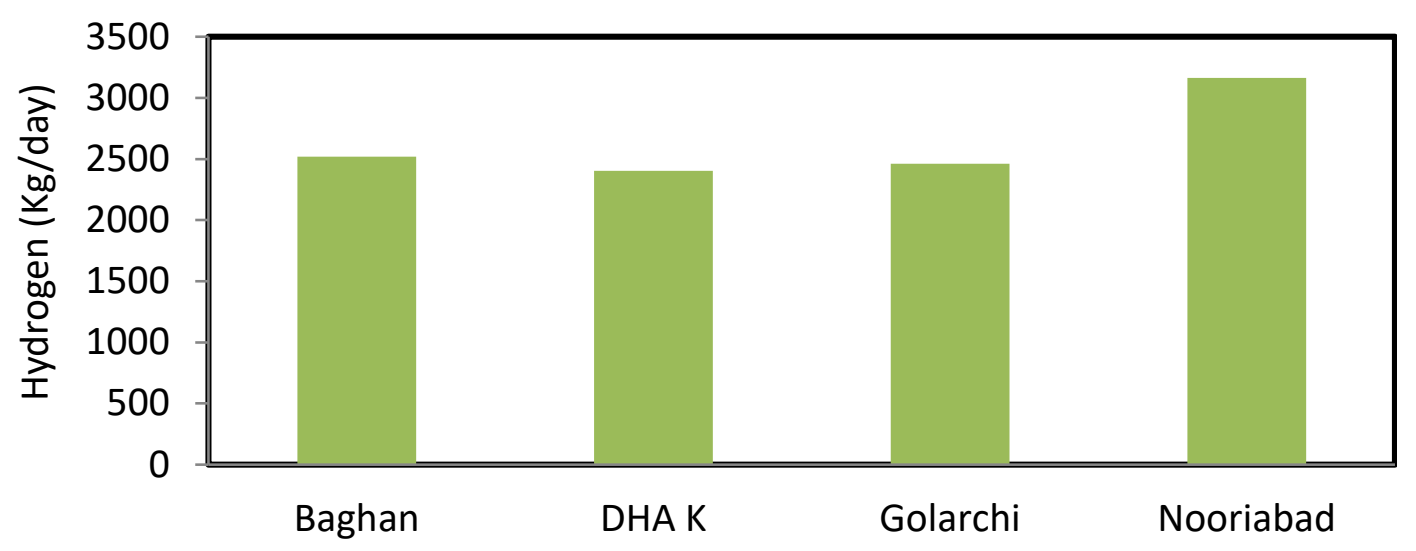

Figure.3 Hydrogen production of proposed sites

If the Pakistani Government makes the decision to install wind hydrogen projects, there is a better opportunity to overcome the electricity shortage especially in the summer season. Using the windgenerated electricity at 4 sites $10,545 \mathrm{~kg} /$ day hydrogen can be produced. Further, the total capacity of Wind generated electricity in Pakistan is $1,19,410 \mathrm{MW}$ which can produce $51917.39 \times 10^{3} \mathrm{~kg} /$ day of hydrogen annually, which is a cheap, clean and safe way to flee the cars and other vehicles in Pakistan. The transportation oil consumption can be used to produce electricity to reduce power shortage.

Hydrogen energy can be used to reduce the use of gasoline fuel and $\mathrm{CO}_{2}$ emission of road transportation. The stored form of hydrogen can be used as renewable fuel and carbon free electricity production at specific areas. Hydrogen energy can be used in chemical industrial process for manufacturing and other purpose, for instance in mixtures of methane $\left(\mathrm{CH}_{4}\right)$ used in auto gasoline. It can also be used for heating and cooking purposes. In addition, it may be used as a hydrocarbon fuel or other synthetic fuel protection, but these options are not discussed because our focus was to provide wind generated hydrogen fuel to decrease the burden of oil so that oil should be consumed to produce electricity in time of emergency. The ultimate objective is to 
reduce the power shortage during the summer season especially during heat waves. The road transport sector is another concerning issue addressed here.

\subsection{Calculation of Renewable Generation cost}

Economic analysis is carried out by assuming the operating and maintenance cost as $25 \%$ of the annual investment cost of wind turbine (lifetime/machine price). The interest rate and inflation rates are 12.63 and 6.9 respectively while wind turbine machine life has been considered as 20 years. The installation and civil work cost is $4 \%$ of investment cost and miscellaneous cost is $10 \%$ of investment cost while the battery cost is taken as $9 \%$ of investment cost. Inverter cost is taken as $4 \%$ of the investment cost of the wind turbine project. We measure the unit cost of electricity generation with the help of the equation (24) by each site and wind turbine cu C $(\$ / \mathrm{kWh})$. The economic and technical consideration used for renewable hydrogen production consists of the capital expenses intended for the system is about $\$ 402$ and annualized the capital expenditure of $\$ 36.8 \mathrm{yr}$. To maintain a renewable hydrogen conversion system the total raw material and operating cost are $\$ 710,000 / y r$ and $\$ 283,000 / y r$ respectively, and the credits reaches about \$20 M/yr. Evaluation of technical characteristics of wind and electricity generation vary from sites to sites. It is assumed that in our study the average wind speed is $8.20 \mathrm{~m} / \mathrm{s}$ to $10.0 \mathrm{~m} / \mathrm{s}$ and the capacity factor of electricity generation is 0.40 at three sites while at Nooriabad sites the capacity factor is 0.50 . From the table 6 it is clear that the Nooriabad site has maximum capacity factor 0.50 and cost is $\$ 0.0868(\$ / \mathrm{kWh})$. Rest of the sites have the average capacity factor of 0.40 (DHA K capacity factor is 0.39$)$ and average cost is $\$ 0.0864(\$ / \mathrm{kWh})$. In Pakistan, electricity price per unit and tariffs vary from states to states with respect to consuming purpose, so overall price changes at the final supply stage is with the given proposed sites. 
Table.4: Price of renewable energy

\begin{tabular}{ll}
\hline Sites & Price in $\$$ \\
\hline Price of electricity at Baghan site & $\$ 0.0864 / \mathrm{kWh}$ \\
Price of electricity at DHA K site & $\$ 0.0868 / \mathrm{kWh}$ \\
Price of electricity at Golarchi site & $\$ 0.0862 / \mathrm{kWh}$ \\
Price of electricity at Nooriabad site & $\$ 0.0868 / \mathrm{kWh}$ \\
Price of hydrogen at all sites & $\$ 4.304 / \mathrm{kg}-\mathrm{H}_{2}$ \\
Supply price of hydrogen at all sites & $\$ 5.30-\$ 5.80 / \mathrm{kg}$ \\
\hline
\end{tabular}

Other sites : DHA Karachi, Baghan and Golarchi

The water and electricity requirements for $1 \mathrm{~kg}$ of the renewable hydrogen generation are and $10.6 \mathrm{~kg}$ and $53.4 \mathrm{kWh}$ respectively. Further assumptions are that the capital cost of renewable hydrogen production per hour is $\$ 2.2$ that includes direct and indirect costs and the operating cost is $\$ 0.027 / \mathrm{kg}$ of renewable hydrogen production. The leveled water supplying cost is assumed (Table 4) about $\$ 4.1 /$ tons of water for simplicity of calculations that does not consider the extra cost of storing water due to the low coupled cost. To repay the capital cost, the interest rate is assumed to be $10 \%$ in Pakistan and the project life time has been considered as 20 years. Therefore, the capital charge factor is 0.10 and 0.115 for the electrolysis system. Further, the selling price of oxygen is assumed to be $\$ 61 /$ ton and $\$ 0.06 / \mathrm{kWh}$. Capital cost electricity production is $87 \%$, hydrogen production is $8 \%$ and hydrogen storage cost is $5 \%$ while operating wind turbine, configuration cost is $51 \%$, gasification cost is $7 \%$, electrolysis cost is $1 \%$, storage operation cost is $10 \%$, raw material cost is $10 \%$ and water supply cost is $20 \%$. The revenue, the hydrogen supply cost, and the breakdown of capital and operating costs shows that the renewable electricity production coordination is the main capital cost component of the production of renewable hydrogen energy. This cost structure is due to the substantial cost of the wind turbine configuration for renewable hydrogen. The total capital cost can be decreased if the wind turbine configuration 
cost per unit cost is lower or the lower cost of raw material. It is because in the electrolysis process the purchase of raw material is the second highest contributor cost in this process system. Economic integration of renewable hydrogen shows the production cost of renewable hydrogen is $\$ 4.304 / \mathrm{kg}$ while its supply cost varies from to $\$ 5.30 / \mathrm{kg}$ to $\$ 5.80 / \mathrm{kg}$ while the supply cost of renewable hydrogen increased due to supply cost. Renewable hydrogen production and supply cost of renewable hydrogen depends upon the quality of wind turbine configuration, alkaline electrolyzer. Efficiency of the electrolysis process ranges from $56 \%$ to $75 \%$. Electrolysis electricity consumption per kilogram of hydrogen production is 52.5 to $53.4 \mathrm{kWh}$. For production of 1000 $\mathrm{kg} /$ day, a unit of $2.3 \mathrm{MW}$ or $20 \mathrm{GWh}$ electricity is annually required. However, the price of electricity and hydrogen can vary during the other months of year due to different wind speed and different capacity factor.

\section{Conclusion and policy implication}

Economic viability, wind characteristics of different sites and wind energy utilization has been investigated to assess the wind power potential for renewable hydrogen production. For this objective a scientific and methodological assessment of wind characteristics have been studied. Summary of wind power potentiality of renewable hydrogen production from the wind-generated electricity in the region of Karachi (Pakistan) has been investigated. The sites of Baghan, Nooriabad, Golarchi and DHA Karachi have been studied where the data of the metrological department of Pakistan is available. Results reveals that all of the sites are commercially viable for renewable hydrogen production. Hydrogen production depends upon the wind speed, air density, the size of the wind turbine and efficiency of the electrolyzer system. The results reveal that using the wind generated electricity at 4 sites, 10,545 $\mathrm{kg} /$ day hydrogen can be produced while the 
hydrogen production in summer season can be optimized up to $51917.39 \times 10^{3} \mathrm{~kg} / \mathrm{day}$ of hydrogen annually by using $660 \mathrm{~kW}$ wind turbines. Moreover, this production can be improved by increasing the efficiency of electrolyzer system. Further, the economics of cost for renewable hydrogen shows the production cost of renewable hydrogen is $\$ 4.304 / \mathrm{kg}$ while its supply cost varies from to $\$ 5.30 / \mathrm{kg}$ to $\$ 5.80 / \mathrm{kg}-\mathrm{H}_{2}$. For renewable hydrogen production from the wind-generated electricity, it is necessary to pick optimal wind site by using the most accurate methodology like adopted in this study. Renewable hydrogen can contribute to reduce electricity shortage.

To address energy crises and climate change concerns, Pakistan should align itself with Renewable Portfolio Standard (RPS) similar to developed economies. The policies of developed economies encourage the renewable hydrogen utilization. For example, currently numerous hydrogen stations are operating in the Düsseldorf city of Germany. Japan has also opened five public hydrogen stations at Nagoya, Toyota, Saga, Fukuoka and Kobe. In contrary, the present energy policy of Pakistan does not encourage utilization of hydrogen energy produced using RE technologies. The present energy resources dominated by thermal power stations increase the $\mathrm{CO}_{2}$ emission and it might reach 55.2 million metric tons by 2030 from 22.2 million metric tons in 2012. Therefore, the policies should be revised to adapt RE technologies while taking measures to deal with less dependency of imported oil, its threats of supply disruption, price fluctuation and fuel storage. . RE development will not only cater to the modern industrial needs but also supply to rural areas ( $71 \%$ population lives in rural areas). The following guidelines could be considered for developing a robust and effective renewable energy policy;

i. Renewable energy technologies (RETs) deployment should increase in Pakistan so that RE can provide larger (minimum 9700 MW by 2030) proportion in total energy mix. 
ii. Entice foreign direct investment in RE sector by introducing and facilitating renewable energy markets to promote the competition for lower prices of RE.

iii. Feed-in-tariffs should be made ease for individual and private energy generation.

iv. RE deployment impact should be optimized in rural areas by assimilating power provision with other societal infrastructure, e.g., sanitation and water supply, medical and educational facilities, telecommunications and roads to endorse the productivity, trade, social welfare and economic well-being.

v. Facilitate and help the technical, institutional and operational capacity to establish the domestic RE to improve the technical skills.

vi. The cars and other transportation could be fueled via renewable hydrogen so that the fossil flues demand should be cut down. In addition, the usage of hydrogen should be ensured in light of Paris agreement.

vii. Decentralized RE production can decrease distributional line losses and theft amounting to $22 \%$. Therefore, the policy should encourage the hybrid and multi grid systems.

The study can be extended to add storage features and to measure the cost of storage of renewable hydrogen. This study can also be extend by increasing the fidelity of the analysis. To address the issue of renewable hydrogen production with minimum availability of wind at windy site may attract researcher for future work. 


\section{References}

[1] Hostettler S. Energy Challenges in the Global South. In Sustainable Access to Energy in the Global South . Springer International Publishing2015;3:9.

[2] Griggs D, Stafford-Smith M, Gaffney O, Rockström J, Öhman M. C, Shyamsundar P, Noble I. (2013). Policy: Sustainable development goals for people and planet. Nature, 495(7441), 305307.

[3] Intergovernmental Panel on Climate Change. Climate Change 2014-Impacts, Adaptation and Vulnerability: Regional Aspects. Cambridge University Press.

[4] Liang R. H, Liao J. H. A fuzzy-optimization approach for generation scheduling with wind and solar energy systems. IEEE Transactions on Power Systems 2007;22(4): 1665-1674.

[5] Strachan P. A, Lal D. Wind energy policy, planning and management practice in the UK: hot air or a gathering storm? Regional Studies 2004;38(5):549-569.

[6] Crawford R. H. Life cycle energy and greenhouse emissions analysis of wind turbines and the effect of size on energy yield. Renewable and Sustainable Energy Reviews 2009;13(9): 26532660.

[7] Connolly D, Lund H, Mathiesen B. V, Leahy M. A review of computer tools for analyzing the integration of renewable energy into various energy systems. Applied Energy 2010; 87(4): 10591082.

[8] Kleijn R, Voet E.V.D. Resource constraints in a hydrogen economy based on renewable energy sources: an exploration, Renew. Sustain. Energy Rev 2010;14 (9): 2784-2795.

[9] Cau G, Cocco D, Petrollese M, Kaer S. K, Milan C. Energy management strategy based on shortterm generation scheduling for a renewable micro grid using a hydrogen storage system. Energy Conversion and Management 2014;87:820-831.

[10] Olateju B, Kumar A. Hydrogen production from wind energy in Western Canada for upgrading bitumen from oil sands. Energy 2011; 36(11): 6326-6339.

[11] Østergaard P. A, Lund H. A renewable energy system in Frederikshavn using low-temperature geothermal energy for district heating. Applied Energy 2011;88(2): 479-487.

[12] Katsigiannis Y. A, Georgilakis P. S, Karapidakis E. S. Multiobjective genetic algorithm solution to the optimum economic and environmental performance problem of small autonomous hybrid power systems with renewable. IET Renewable Power Generation 2010;4(5): 404-419.

[13] Sacramento E. M. De Lima L. C, Oliveira C. J, Veziroglu T. N. A hydrogen energy system and prospects for reducing emissions of fossil fuels pollutants in the Ceará stateBrazil. International Journal of Hydrogen Energy 2008; 33(9): 2132-2137. 
[14] Ball M, Wietschel M. The future of hydrogen-opportunities and challenges. International journal of hydrogen energy 2009;34(2): 615-627.

[15] Dagdougui H., Ouammi A, Sacile R. A regional decision support system for onsite renewable hydrogen production from solar and wind energy sources. international journal of hydrogen energy 2011; 36(22): 14324-14334.

[16] Bekele G, TadesseG. Feasibility study of small Hydro/PV/Wind hybrid system for off-grid rural electrification in Ethiopia. Applied Energy 2012;97: 5-15.

[17] Guo Y, Ru P, Su J, Anadon L. D. Not in my backyard, but not far away from me: Local acceptance of wind power in China. Energy 2015;82:722-733.

[18] Akpinar S, Akpinar EK. Estimation of wind energy potential using finite mixture distribution models. Energy Conversion \& Manage 2009;50:877-84.

[19] Mohammadi K, Alavi O, Mostafaeipour A, et al. Assessing different parameters estimation methods of Weibull distribution to compute wind power density. Energy Conversion \& Manage 2016;108(15):322-35.

[20] Ozay C, Celiktas M.S. Statistical analysis of wind speed using two-parameter Weibull distribution in Alaçatı region. Energy Conversion Manage 2016;121 (August):49-54.

[21] Shu ZR, Li QS, Chan PW. Statistical analysis of wind characteristics and wind energy potential in Hong Kong. Energy Conversion \& Manage 2015;101 (September): 644-57.

[22] Hill D. C, McMillan D, Bell K. R, Infield D. Application of auto-regressive models to UK wind speed data for power system impact studies. IEEE Transactions on Sustainable Energy 2012; 3(1): 134-141.

[23] Tsekouras G, Koutsoyiannis D. Stochastic analysis and simulation of hydro meteorological processes associated with wind and solar energy. Renewable Energy 2014; 63: 624-633.

[24] Wais P. Two and three-parameter Weibull distribution in available wind power analysis. Renewable Energy 2017;103:15-29.

[25] Khahro S. F, Tabbassum K, Soomro A. M, Dong L, Liao X. Evaluation of wind power production prospective and Weibull parameter estimation methods for Baburband, Sindh Pakistan. Energy conversion and Management 2014;78: 956-967.

[26] Shin J. Y, Ouarda T. B, Lee T. Heterogeneous mixture distributions for modeling wind speed, application to the UAE. Renewable Energy 2016;91: 40-52.

[27] Boudries R, Dizene R. Potentialities of hydrogen production in Algeria. international journal of hydrogen energy 2008;33(17): 4476-4487. 
[28] Dincer I, Acar C. Innovation in hydrogen production. International Journal of Hydrogen Energy 2017.

[29] Oh J, Koo C, Hong T, Jeong K, Lee M..An economic impact analysis of residential progressive electricity tariffs in implementing the building-integrated photovoltaic blind using an advanced finite element model. Applied Energy 2017;202: 259-274.

[30] Kalinci Y, Dincer I, Hepbasli A. Energy and exergy analyses of a hybrid hydrogen energy system: a case study for Bozcaada. international journal of hydrogen energy 2017;42(4): 24922503.

[31] Kalinci Y, Hepbasli A, Dincer I. Techno-economic analysis of a stand-alone hybrid renewable energy system with hydrogen production and storage options. International Journal of Hydrogen Energy 2015;40(24): 7652-7664.

[32] Onovwiona H. I., Ugursal V. I. Residential cogeneration systems: review of the current technology. Renewable and sustainable energy reviews 2006;10(5): 389-431.

[33] Mohammed Y. S, Mustafa M. W, Bashir N. Hybrid renewable energy systems for off-grid electric power: Review of substantial issues. Renewable and Sustainable Energy Reviews 2014; 35: 527-539.

[34] Mendes G, Ioakimidis C, Ferrão P. On the planning and analysis of Integrated Community Energy Systems: A review and survey of available tools. Renewable and Sustainable Energy Reviews 2011;15(9):4836-4854.

[35] Lund P. D, Lindgren J, Mikkola J, Salpakari J. Review of energy system flexibility measures to enable high levels of variable renewable electricity. Renewable and Sustainable Energy Reviews 2015;45: 785-807.

[36] Jebaraj S, Iniyan S. A review of energy models. Renewable and Sustainable Energy Reviews 2006;10(4): 281-311.

[37] Forsberg C.W. Future hydrogen markets for large-scale hydrogen production systems. International Journal of Hydrogen Energy 2007;32(4): 431-439.

[38] Sarrias-Mena R, Fernández-Ramírez L. M, García-Vázquez C. A, Jurado F. Electrolyzer models for hydrogen production from wind energy systems. International Journal of Hydrogen Energy 2015; 40(7): 2927-2938.

[39] Valverde-Isorna L, Ali D, Hogg D, Abdel-Wahab M. Modeling the performance of windhydrogen energy systems: Case study the Hydrogen Office in Scotland/UK. Renewable and Sustainable Energy Reviews 2016; 53: 1313-1332. 
[40] Erdinc O, Uzunoglu M. A new perspective in optimum sizing of hybrid renewable energy systems: consideration of component performance degradation issue, Int. J. Hydrog. Energy 37 (14) (2012) 10479-10488.

[41] Carta J. A, Velázquez S, Cabrera P. A review of measure-correlate-predict (MCP) methods used to estimate long-term wind characteristics at a target site. Renewable and Sustainable Energy Reviews 2013; 27: 362-400.

[42] Mathew S. Wind energy: fundamentals, resource analysis and economics (Vol. 1). Heidelberg: Springer 2006.

[43] Sultan A. Y, Charabi Y, Gastli A, Al-Alawi S. Assessment of wind energy potential locations in Oman using data from existing weather stations. Renewable and Sustainable Energy Reviews 2010;14(5): 1428-1436.

[44] Gökçek M, Genç M. S. Evaluation of electricity generation and energy cost of wind energy conversion systems (WECSs) in Central Turkey. Applied Energy 2009; 86(12): 2731-2739.

[45] Joskoaw P. L. Comparing the costs of intermittent and dispatch able electricity generating technologies. The American Economic Review 2011;101(3); 238-241.

[46] Chathuranga J. K, Wijayapala W. S, Wijayatunga P. D. C. (2016, December). Mainstreaming renewable energy developments into traditional planning: A Sri Lanka case study. In Electrical Engineering Conference (EECon) 2016;59-67). IEEE.

[47] Clarke R. E, Giddey S, Ciacchi F. T, Badwal S. P. S, Paul B, Andrews J. Direct coupling of an electrolyzer to a solar PV system for generating hydrogen. International Journal of Hydrogen Energy 2009;34(6): 2531-2542.

[48] Herdem M. S, Farhad S, Dincer I, Hamdullahpur F. Thermodynamic modeling and assessment of a combined coal gasification and alkaline water electrolysis system for hydrogen production. International Journal of Hydrogen Energy 2014; 39(7): 3061-3071.

[49] Udagawa J, Aguiar P, Brandon N. P. Hydrogen production through steam electrolysis: Modelbased steady state performance of a cathode-supported intermediate temperature solid oxide electrolysis cell. Journal of Power Sources 2007;166(1):127-136.

[50] Harijan K, Uqaili M., Memon M, Mirza U. Potential of on-shore wind power in the coastal areas of Baluchistan, Pakistan. Wind Engineering 2010; 34(2): 167-180. 